\title{
LEAPFROGGING TOWARDS GREEN INFRASTRUCTURE - A CASE OF AFRICAN AVENUE
}

\author{
MOSISSA SAMUEL ${ }^{1}$, SHEN ZHONGWEI ${ }^{1}$, TSEGAYE WUBENGDA ${ }^{1} \&$ EYOB ABEL $^{2}$ \\ ${ }^{1}$ Southwest Jiaotong University, China \\ ${ }^{2}$ EIABC, Ethiopia
}

\begin{abstract}
Green infrastructure supports urban areas by linking environmental, social and economic roles of other infrastructural developments, like connecting transport infrastructures with nature. Diverse street designs provide multiple benefits, such as carbon sequestration, flood management, reduced traffic accidents, wildlife habitat, neighbourhood beautification, improved air quality, noise pollution and more related to green infrastructure benefits. Thus, this article's first objective is to explore green infrastructure benefits and identify those related to transportation. Furthermore, allocate a category of multifunctionality for African avenue/Bole Street with experts' opinions. What green infrastructure benefits do the pavement, bioswales, planter boxes, trees and Bole/African avenue road altogether deliver? The second is to see the transportation planning of Addis Ababa, first by reviewing its environmental impact on the city and second by taking the case of African avenue/Bole street, which has gone in the process of widening. Since one benefit of GI is reducing traffic accidents, this road is built to reduce traffic accidents. We checked if it reduced traffic collisions occurring on African Avenue. Its direct accidental impact, injuries sustained in road traffic collisions are gathered and compared between the years before and after the widening of African avenue.

The GI value difference result indicates a considerable gap between the possible benefits the street could give and the current benefits. Transport impact on the city's environmental health is vast. Collisions on vehicles increased and the number of pedestrians affected increased; Thus, the papers suggest Addis Ababa needs to increase employed GI strategies and integrate new green infrastructure strategies to intensify multifunctionality. Moreover, the paper introduces the concept of Leapfrog and the possibility of shifting into green transportation.
\end{abstract}

Keywords: Addis Ababa, green infrastructure (GI), leapfrog, traffic accidents, GI benefits.

\section{INTRODUCTION}

Transport and green infrastructure have been attracted attention for ages. Interest in this subject has significantly increased since the 1970s. Many publications address the ecological effects of roads and traffic [1], Types of impact such as traffic accidents, emissions, noise, air cooling, stormwater.

It is crucial to establish green infrastructure to neutralize urban runoff, urban cooling, carbon sequestration and traffic accident impact of roads [2]. Since the transport sector has an immense impact on the environment, it can also reverse it if unified with green infrastructure [3]. It is more resilient, cost-effective and meets 21 st century needs than grey infrastructures [4]. The research aims to find the benefits of green infrastructure in the transportation sector and use those benefits to evaluate African avenue.

GI provides a multifunctional infrastructure that is connected. Connecting a network of spaces and a more comprehensive range of functions demonstrates the benefits that GI can deliver [5]. The fundamental similarity between green infrastructure and transportation planning is creating connections and functioning networks, but the conflict seeks to connect in the same landscape and regions. According to Addis Ababa city Government plan commission [6], the city is losing its green coverage at a devastating speed. Climate change, flash floods, heatwaves and drought are significant environmental problems related to the city [7]. 
Recently, Addis Ababa's city is making efforts to recover the city's condition [8,9]. Given the significance, further study needs to show the value of GI and the degree of multifunctionality. Spaces and a more comprehensive range of functions demonstrate the benefits that GI can deliver [5]. The fundamental similarity between green infrastructure and transportation planning is to create connection and functioning networks, but the conflict is to create this connection in the same landscape and regions. According to Addis Ababa city Government plan commission [6], the city is losing its green coverage at a devastating speed. Climate change, flash floods, heatwaves and drought are significant environmental problems related to the city [7]. Recently, Addis Ababa's city is making efforts to recover the city's condition [8,9]. Given the significance, further studies need to show the value of GI, measure indicators and the degree of multifunctionality, which is the paper's primary objective.

\section{METHODOLOGY}

The first part of the research methodology searches and identifies the main benefits of green infrastructure and determines GI deliveries' services. With the GI benefits, a description and measure indicators are prepared that enables experts to assess the African avenue/Bole street context with the pavement, bioswales, planter boxes, trees, and the road as a general. Through academic expert's inputs, maps and data collected from concerned offices. The method [10,11] are adopted for the first part of the research. Green infrastructure benefits and their multifunctionality method [10] to produce a framework for multi-functional green infrastructure assets, and expert opinion [11] is adopted to identify linkages between green infrastructure and services using an expert opinion methodology. Academic experts identified, from available information of Ethiopian Institute of Architecture, Building Construction and City development department lists and networking with experts willing to cooperate, who already studied Addis Ababa's green issues and transportation.

Furthermore, four transport Police officers who witnessed the change of African avenue worked on that segment before and after redevelopment, with experience of more than six years, were selected from bole sub-city traffic police station - a total of 14 experts involved. With a list of GI benefits, a description, and measure indicators, the experts give value, and the value difference calculated, which is the difference between the asset's possible GI benefits (PGIB) with the asset's current GI benefits (CGIB). We used a relative percentage differences calculator to determine the GI value relative percentage difference, which converts the GI value difference to a percentage. The higher the relative Percentage difference is, the higher the asset needs attention [12].

$$
\text { GI value relative Percentage difference }=\left(\frac{[P G I B-C G I B]}{(P G I B)}\right) \times 100
$$

The second part of the methodology helps to see, environmental and traffic accidental impact of Addis Ababa transport planning in the city. Traffic accidents in African avenue/Bole, located in the two most accident-prone sub-cities and one of the busiest roads with traffic flows, is selected to show the trend solution in the city.

The selected site allows the research to compare the pros and cons of the redevelopmenttraffic collision data collected before the renewal of the road and after construction. Our data source was traffic collisions in African Avenue/Bole Road, collected by Addis Ababa bole sub-city police commission, traffic control and inspection office. Concerning the data's 


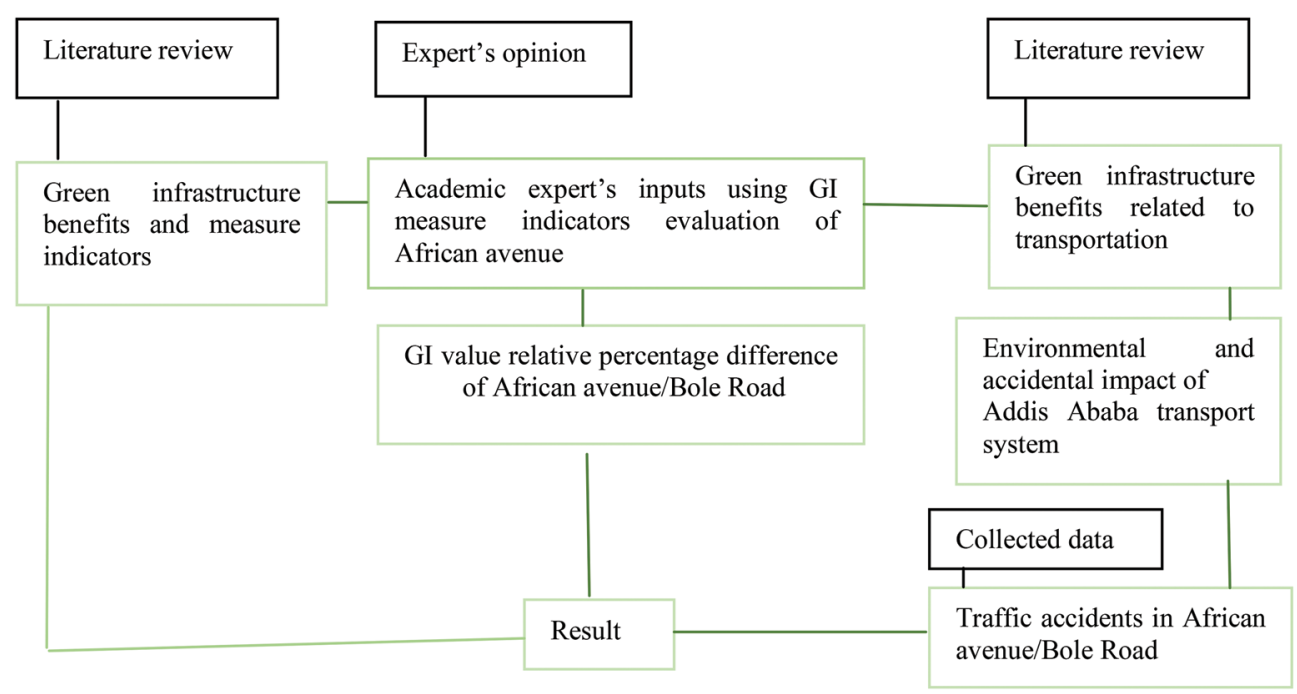

Figure 1: Method outline.

quality and validity, we checked every single report done by the traffic officers when the collisions occurred and counted it from the stored source file. Since they do not have separated data for each street, we separated the African avenue/Bole road reports from the other streets. Observations and collection of relevant photos and illustrative diagrams used to explain scenarios and situations under discussion.

\subsection{Green infrastructure benefits}

Connecting green infrastructure assets to a broader network of spaces increases their benefits [12].

2.1.1 List of GI benefits and measure indicators

This section demonstrates review findings on the summaries of benefits that GI can deliver [12]. The benefits of GI and measure indicators examine Bole Road context with the pavement, bioswales, planter boxes, trees, footpath and car path altogether deliver.

The expert's opinion on the chosen site is summarized, to determine the GI value difference multifunctionality level.

\subsection{Addis Ababa transport impact}

In today's cities like Addis Ababa, transport impact on most people falls outside the scope of the calculations. At the same time, the benefits of increased vehicle traffic volumes and speeds are recognized. However, environmental impact and reductions in walkability are often overlooked. The negative environmental impact of mobility-based transport planning has become undeniable and critical [46]. Such planning practices can reduce travel options, increase traffic collisions and encourage sprawl [47].

Additionally, it has a consequence on the environment. "Currently, transportation represents $68 \%$ of the city's greenhouse gas (GHG) scope 1 emissions" [48]. Furthermore, Fine 


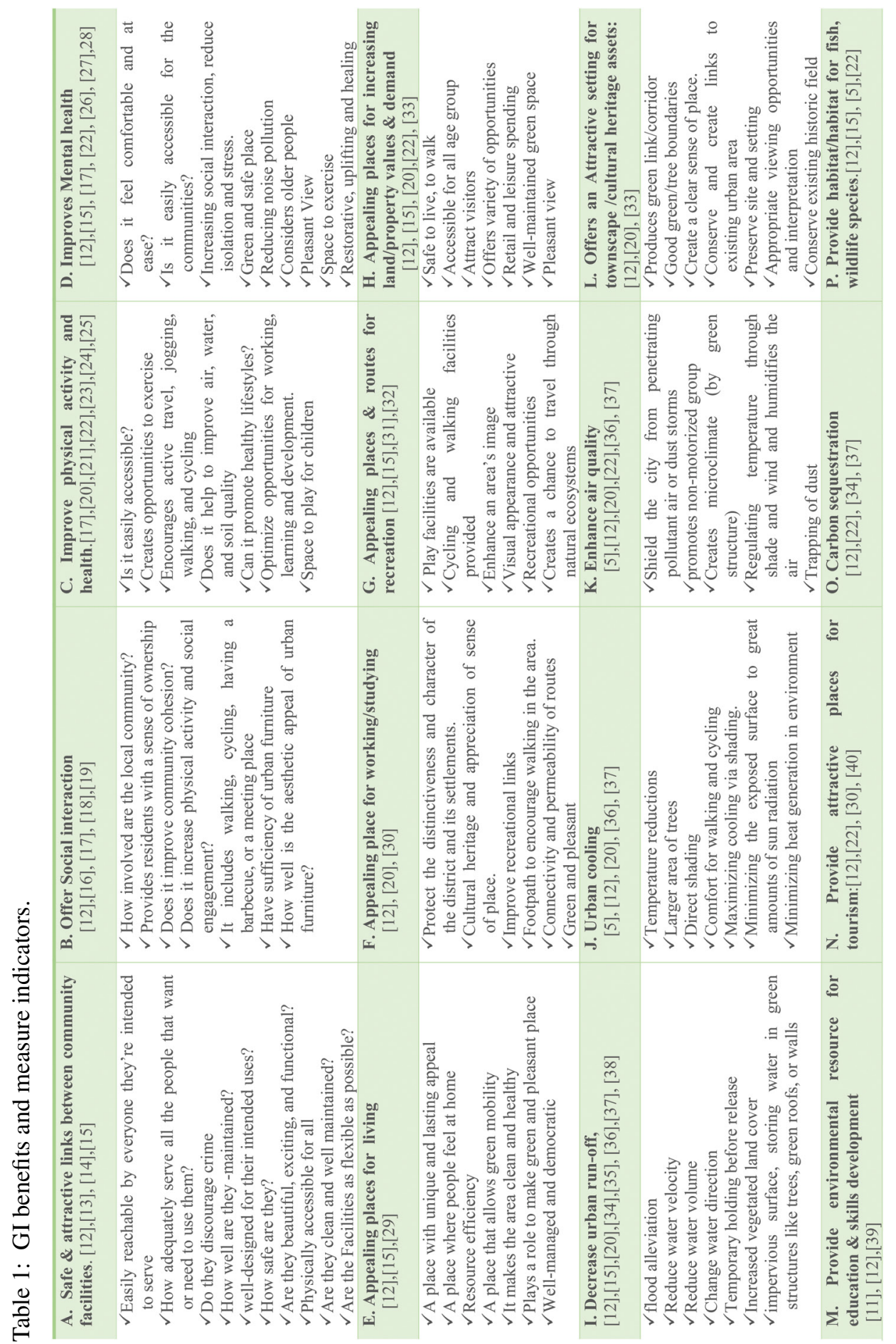




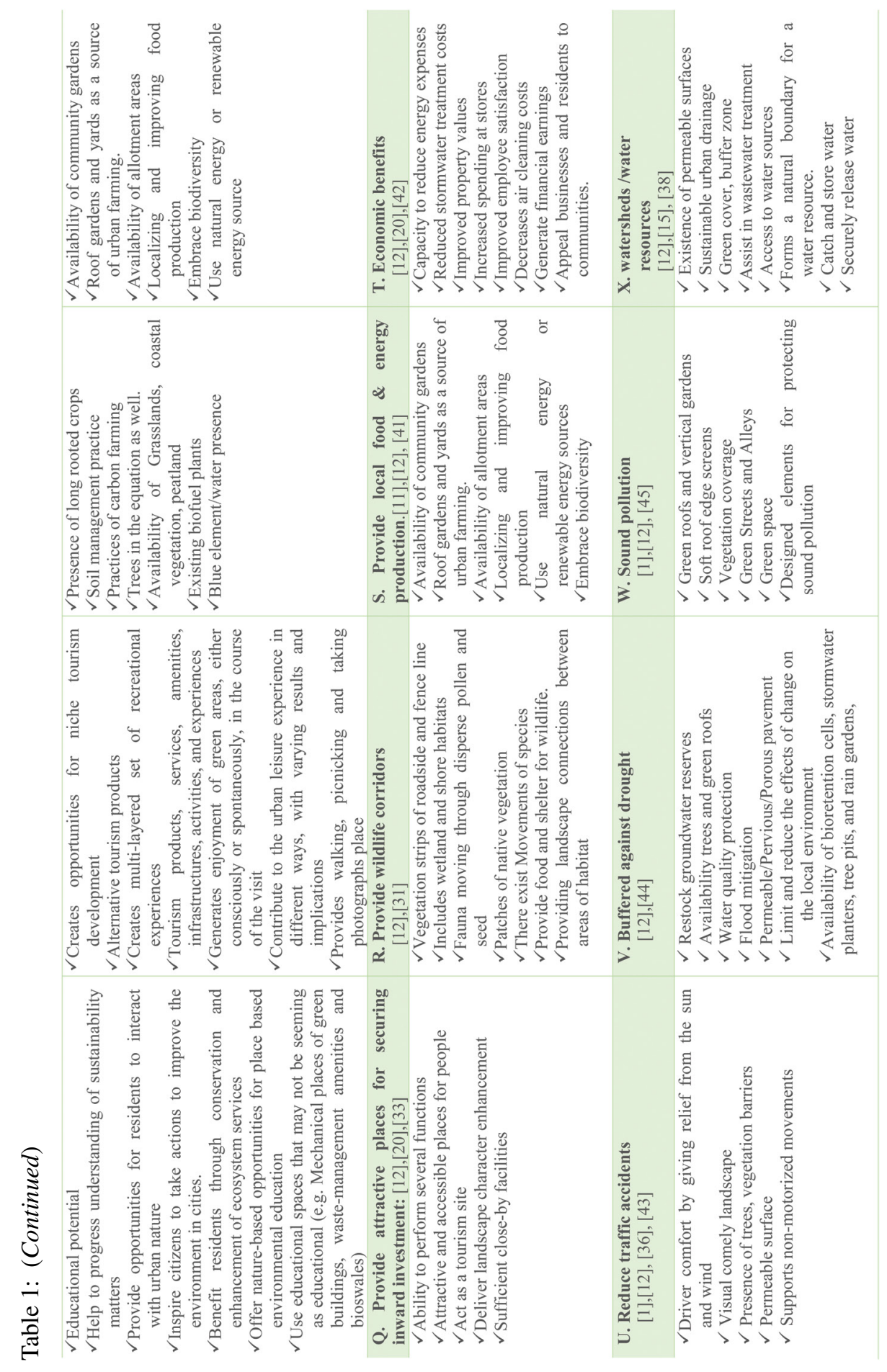


Table 2: Sample to illustrate expert's opinion table. The experts listed from 1 to 14 evaluated the benefits listed in 2.1 from A to $\mathrm{X}$ in Bole road.

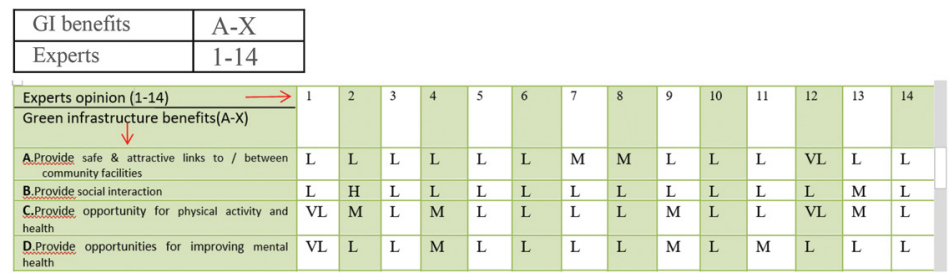

particulate matter (PM2.5) annual average concentration is twice the World Health Organization guidelines, which raises serious health concerns for the city citizens [49]. Indifferent from the history of the developed world transport system, Addis Ababa transport planning is trying its best to make the city suitable for motorization. Conversely, $70 \%$ of the population is pedestrian [50]. Even though Addis Ababa has a low road network density and vehicle ownership, cited as the worst example of traffic accidents. Considering the trend of road crashes in Addis Ababa, Ethiopia, ultimately, the opposite is evident; Addis Ababa and the country face a high rate of traffic collisions despite low car ownership. The death rate by traffic collisions reaches at least 114 per 10,000 vehicles per year, while in the UK and Ireland, only 10 and 60 [51]. According to the review, Addis Ababa, Ethiopia's capital city shares more than $60 \%$ of the traffic collisions in the country; pedestrians were the most affected, taking $79 \%$ of the total injuries.

According to the Addis Ababa police commission report, 391 people lose their lives on Addis Ababa streets each year. Even it might be bigger than that, according to [52] referencing the world health organization, the actual number is six times the reported number. If history has been taught as right, automobile-oriented development has caused many misshapes to society.

\subsubsection{African avenue/bole road}

It is located at the west of bole sub-city and south of the kirkos sub-city. It is the main road that connects Addis Ababa international airport and Meskel square. According to the traffic officers, the road is called VIP street since most international gusts use the road as an entrance and exit from the city. So it has a considerable value in showing the city image. The width of the road increased to eliminate traffic collisions and traffic congestion. The data collected in this road segment helps evaluate the strategy to increase roads' width if it helps eliminate traffic collisions. The research tried to seek if road construction helped reduce traffic jams and traffic collisions as intended? Furthermore, seek if it has created multifunctionality in green infrastructure.

The study tries to show an overview of the recent road infrastructure development in Addis Ababa but primarily focusing on the road from Meskel Square to Bole AirPort, African Avenue/Bole Road. The premises for the selection of this specific site are

- African Avenue's recent construction provides the research with conditions that best represent the current transport planning and delivery system. Addis Ababa city road authority (AACRA) has launched a road development program to upgrade, rehabilitate and expand the city road network. AACRA considers the African avenue project as exemplary for the development program. 


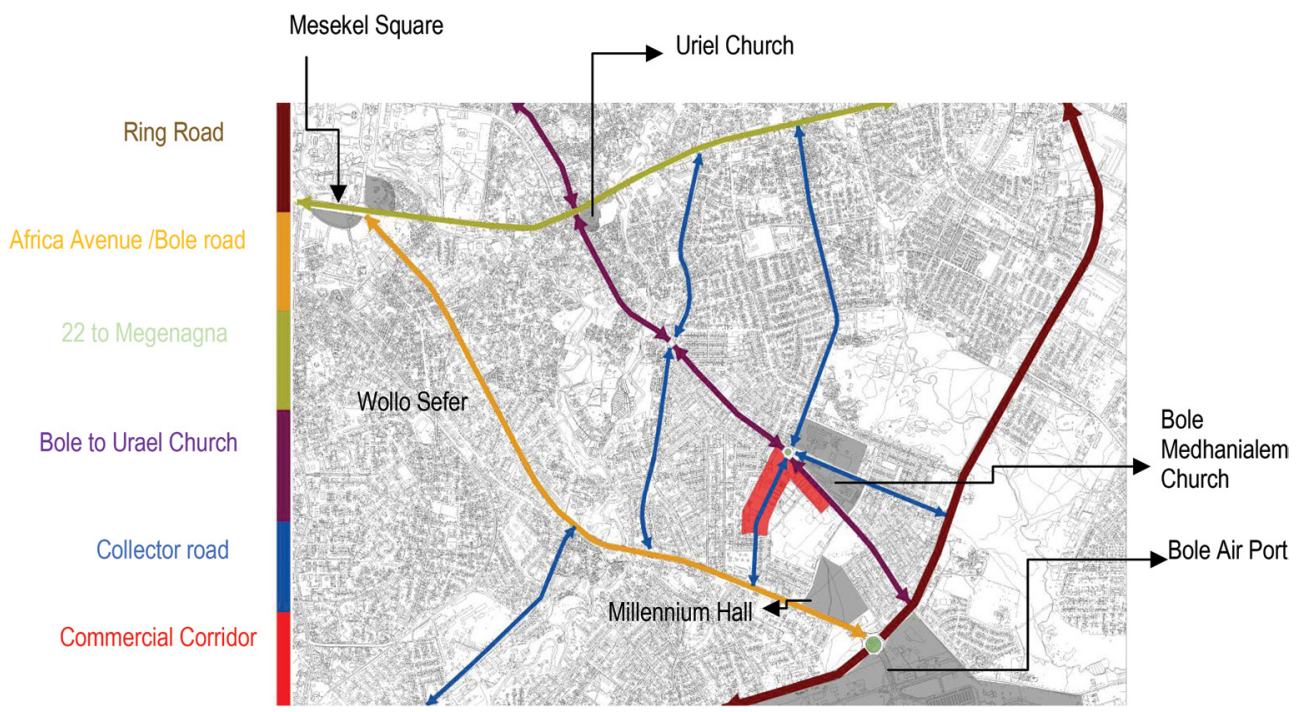

Figure 2: Location of African avenue/Bole road. Source: [6].

- The reason for constructing and updating African avenue gives a benchmark to compare it with its former condition.

- The symbolic importance of the path as it is the gateway to the city and main corridor of the city.

- It is found in the two top sub-cities experiencing the highest rate of car accidents involving pedestrians in Addis Ababa.

\section{RESULTS}

We explored the pavement, bioswales, planter boxes, trees and the road of Bole/African avenue altogether deliver with a possible 24 GI benefits to analyse the estimated value differences and categories of multifunctionality. Figure 3 shows the results of the model based on the expert's view. It uses the measurement of the category of multifunctionality (VL 4 and less, L 5-6, M 7-8, H 9-10, VH 11 and above). It is a very low category of multifunctionality; considering the possible benefits gained from the asset, the result indicates that attention is needed [12].

The relative percentage difference calculator indicates that the lower the current GI assets benefits are, the higher the difference is and vice versa [12]. The GI value percentage difference between Bole street's possible GI benefits and Bole's current GI benefits (PGIB and CGIB) is $69.23 \%$, making the GI value difference gap high. The GI value difference results and categories of multifunctionality indicate a need for attention to GI strategies. Figure 4 shows the difference between the possible GI asset benefits and the current benefit that they are giving, indicating which GI benefit needs attention and can help the transport sector.

One of the benefits of green infrastructure is the reduction of traffic accidents. According to the expert's opinion and the data supported, Addis Ababa has a high traffic accident rate [53], and bole road follows the same trend. 
Table 3: Identified current GI benefits in Addis Ababa ,through experts opinion.

\begin{tabular}{|l|l|l|}
\hline Site & Identified current GI benefits(CGIB) & Identified Potential GI benefits(PGIB) \\
\hline $\begin{array}{l}\text { Bole/Afric } \\
\text { an avenue }\end{array}$ & $\mathrm{E}, \mathrm{F}, \mathrm{H}, \mathrm{L}(4)$ & $\mathrm{A}, \mathrm{B}, \mathrm{C}, \mathrm{G}, \mathrm{I}, \mathrm{J}, \mathrm{K}, \mathrm{O}, \mathrm{P}, \mathrm{R}, \mathrm{S}, \mathrm{U}, \mathrm{W}(13)$ \\
\hline
\end{tabular}

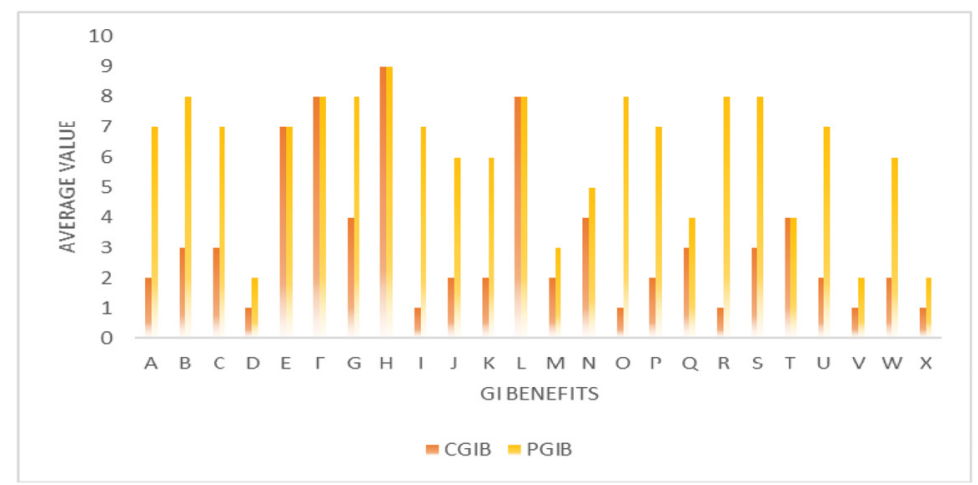

Figure 3: GI value difference.

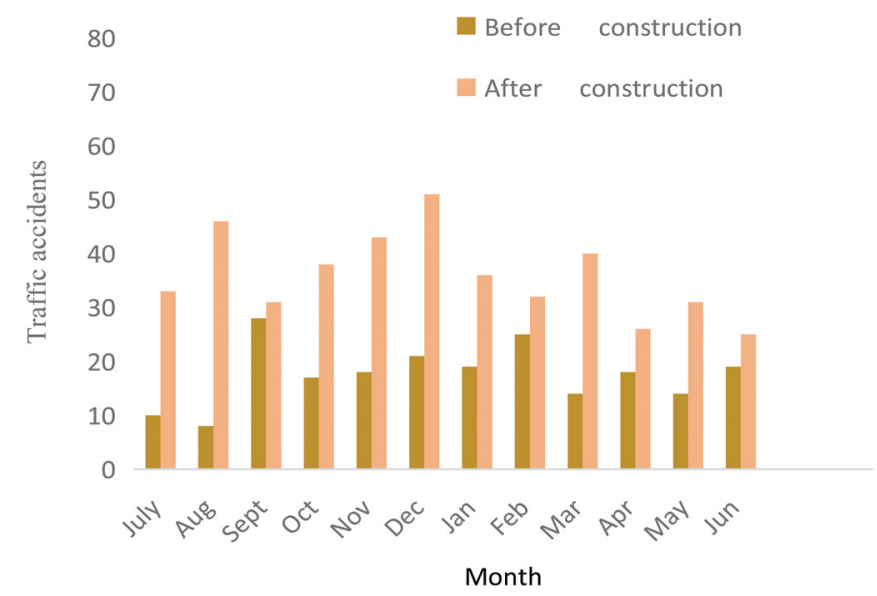

Figure 4: Monthly report on the total collisions on vehicles and pedestrian before and after construction of the road.

3.1 Traffic accidents, in African avenue (bole taxi station up to Wollo sefer)

We collected this data from the bole sub-city traffic police's report. Since the office does not have specific data on every individual accident, we analysed every written statement of the traffic police officers in the period needed for the paper and dragged reports of every collision and injury in the sub-city from July 2011 to August 2012, from July 2013 up to August 2014. 
September 2013, up to the end of June, the road was at construction and out of service. We chose this period to show the collisions and injury rate before and after the construction or the widening of the African avenue project.

Figure 5 shows the widening of the street did not reduce accidents, especially on pedestrians. The pedestrians impacted by the collision rate increase every month.

\section{DISCUSSIONS}

After the experts explored transportation elements in African avenue and used GI benefits as an evaluator, the paper found road safety as a sensitive issue in the current trend of Addis Ababa transportation planning. The main reason African avenue was modified was to ensure road safety, lower environmental impact and decrease congestion. However, the existing transport system is characterized by high accident levels, high traffic congestion and negative environmental impacts; studies [51,56] support the same conclusion. All the questioned officers mentioned that widening the existing road attracted more traffic to the streets, which increased collisions. Experts also noted that an increase in the road width does not consider green elements and pedestrians, reveals the deaths and injuries in road accidents, greenhouse gas emissions, noise and environmental impacts of traffic congestion. The paper suggests green infrastructure benefits as a measuring tool to leapfrog from the current experience and adopt sustainable strategies.

\subsection{Leapfrog}

The study's findings revealed that environmental impact and traffic accidents are increasing in Addis Ababa. On the other hand, the study shows how green infrastructure development has an immense benefit and can be used as a framework. A transportation scheme without undesirable impacts or minor impacts is not only wanted but also crucial. Luckily, it is technologically possible, but government strategies and social attitudes would need substantial changes and leapfrog from the current trend. Therefore, it is premised that leapfrog to green infrastructure should put technical methods in association with suitable economic strategies and management practices.

The concept of leapfrogging suggests that there is a potential for developing cities like Addis Ababa to learn from the developed world's paths. Learn from the mistakes they made and avoid them. Cities like Addis Ababa, which are at the early stage of infrastructure development, have options to take an efficient way. So why not leapfrog? "Technological leapfrogging refers to a process in which developing countries can bypass intermediate development steps and progress directly to more advanced technological options" [54]. Macmillan dictionary defines the word leapfrog as "to go straight from a job or position that was lower in status than someone is to one that is higher than theirs" [55]. According to Todd Litman, "in urban transport, this process could infer a move directly to more sustainable transport options rather than committing to a predominantly auto-based urban form" [57].

The hierarchy of urban transport through an evolutionary process has five stages. The lowermost stage is the time where trips are made by foot to access needs. Then follows where minibus vehicles support trips. Then comes in the middle, two-wheel vehicles; next comes, complete motorization stage (private cars and limited public transport); at the top of the pyramid comes green transportation with more sustainable options [56]. The question for a city like Addis Ababa is to see the possibility of leapfrogging and how? The city is in the paratransit dominant stage at the bottom of the pyramid. Minibusses (vans) provide most 
public transport, so it is possible to leapfrog to the top of the pyramid before going through the remaining stages.

As [57] suggests, a city like Addis Ababa can move directly towards the top of the pyramid where green transport and not motorized infrastructures dominate since motorization levels are still relatively low. Curitiba has become a source of inspiration for other cities aspiring for smart status but low cost $[58,59]$. The case of Curitiba indicates a possibility for the developing world to take a chance and leap 40-70 years of transport planning experience that led to more construction of new roads and transport infrastructure. This loop of increased car, adding roads, increased congestion and accidents have led to a decrease in the quality of urban life.

\section{CONCLUSIONS}

The construction of new roads and maintaining the existing ones is increasing throughout the years; evaluating constructed roads through GI measurements indicates the need to leap current trend. GI delivers an adverse range of benefits—environmental, economic and social benefits to urban dwellers. The listed benefits and measure indicators in Table 1 can be adopted to measure infrastructure in green and grey developments and identify its multifunctionality. While the term GI has been around for a long time, it is still essential to promote GI benefits. The identified benefits of GI assets have room for further study even though this study tried to investigate numerous studies. A more accurate view of green infrastructure assets and their benefits helps local governments, professionals and communities decide where, when and to what extent green infrastructure practices should become part of future planning. This study shows the direction for further research and helps to evaluate and identify GI asset that needs attention. Furthermore, this study can be used as a checklist for the new ongoing projects in the city.

\section{ACKNOWLEDGEMENTS}

We would like to express our special gratitude for the experts involved. Here is a list of names involved in one way or another from people who helped us to collect data, site investigation and experts involved in the evaluation. Gashaw Abera (ITDP country manager), Deputy Sergeant Destaw Aragew, Sergeant Demelash Mengste, Deputy Inspector Endeshaw Asefa, Deputy Sergeant Birhanu Assefa, Amanuel Gethahun (heritage and stormwater expert); Ahmed Mukhtar (urban designer); Amehaselassie Damtew (data collector); Beniam Geberu (urban planner and Heritage expert); Bezawit Getachew (urban economist); Brook Tesfamichael (environmental and chemical engineer); Eden Teklemariam (landscape and environmental planner); Haftom Asmelash (architect and urban planner), Negede Tesfaye (land management) Wubengeda Tsegaye (landscape and environmental planner); Zebad Alemayehu (urban planner and environmental planner). This report would not have been possible without all these people's involvement.

\section{REFERENCES}

[1] Coffin, A.W., From roadkill to road ecology: a review of the ecological effects of roads. Journal of transport Geography, 15(5), pp. 396-406. DOI: 10.1016/j. jtrangeo.2006.11.006, 2007.

[2] Gadziński, J., The impact of EU policies on the modernization of transport infrastructure in Poznań and other major Polish cities. In: P. Churski \& T. Stryjakiewicz (eds.), Poznań - an attempt to assess changes during 10 years of membership in the European Union, pp. 79-90. Poznań, Bogucki Wydawnictwo Naukowe, 2014. 
[3] Mackenzie Schoonmaker and Fred Wagner, Green Infrastructure in the Transportation Sector, Transportation Research Board Webinar. TRB Webinar I Green Infrastructure in the Transportation Sector.Beveridge and Diamond PC,2015.

[4] Landscape Institute."Green Infrastructure, An Integrated Approach to Land Use. Landscape Institute Position Statement".2013 online, https://www.landscapeinstitute. org/policy/green-infrastructure/. accessed 8 Sept. 2019.

[5] Briony A., Norton, A.M., Coutts, S.J., Livesley, R.J., Harris, A.M., Hunter, N.S.G., Williams, Planning for cooler cities: a framework to prioritise green infrastructure to mitigate high temperatures in urban landscapes. Landscape and Urban Planning, 134, pp. 127-138, 2014.

[6] Addis Ababa city, plan commission office, 2019.

[7] Jalayer, F. \& Herslund, Lise \& Cavan, Gina \& Printz, Andreas \& Simonis, Ingo \& Bucchignani, Edoardo \& Jean-Baptiste, Nathalie \& Hellevik, Siri \& Fekade, Rebka \& Nebebe, Alemu \& Woldegerima, Tekle \& Habtemariam, Liku \& Workneh, Abraham \& Yonas, Nebyou \& Bekele, Essete \& Yeshitela, Kumelachew. Climate change induced risk analysis of Addis Ababa city (Ethiopia). Vol. 15 EGU2013-9457, 2013.

[8] https://www.itdp.org/wp-content/uploads/2020/01/In-Ethiopia-New-Leadership

[9] https://edition.cnn.com/2019/07/29/africa/ethiopia-plants-350-million-trees-intl-hnk/ index.html accessed ,3 Feb 2020.

[10] Bradford city center GI study. https://www.bradford.gov.uk/Documents/City Centre Action Plan/Publication/draft/Evidence base/Green infrastructure study, 2014.

[11] Elliott, R.M., Motzny, A.E., Majd, S., Viteri Chavez, F.J., Laimer, D., Orlove, B.S., \& P.J. Culligan, Identifying linkages between urban green infrastructure and ecosystem services using an expert opinion methodology. Ambio, 49, 569-583. https://doi. org/10.1007/s13280-019-01223-9, 2020.

[12] Samuel, M., Zhongwei, S., Gashaw, A. \& Amanuel, W., Green infrastructure benefits to value and enhance the built environment: the case of Addis Ababa, Ethiopia. WIT Transactions on Ecology and the Environment, 241, WIT Press, 2020. ISSN 1743-3541.

[13] Burley, B.A., Green infrastructure and violence: do new street trees mitigate violent crime?, Health \& Place, 54. pp. 43-49, 2018.

[14] Suppakittpaisarn, P., Jiang, X., Sullivan, W.C., Green infrastructure, green stormwater infrastructure, and human health: a review. Current Landscape Ecology Report, 2, pp. 96-110, 2017.

[15] Benedict, M. and McMahon, E., Green infrastructure linking landscapes and communities. Vol. Washington, DC: Island Press, 2006.

[16] Mohd Hisyam Rasidia, Nurzuliza Jamirsahb, Ismail Saidc. Urban Green Space Design Affects Urban Residents' Social Interaction.Cairo ASIA Pacific International. Conference on Environment-Behaviour Studies Mercure Le Sphinx Cairo Hotel,Giza, Egypt, 31 October-2 November 2012@ 2012 The Authors. Published by Elsevier Ltd

[17] Tzoulas K., Korpela K., Venn S., Yli-Pelkonen V., Kazmierczak A., Niemela J., James P., Promoting ecosystem and human health in urban areas using green infrastructure: a literature review. Landscape and Urban Planning, 81, pp. 167-178. DOI: 10.1016/j. landurbplan.2007.02.001.

[18] Marusic, B.G., Social behaviour as a basis for design and development of green infrastructure, urbani-izziv/10.5379. Pages130-149, 2015.

[19] Cohen, D.A., Inagami, S., Finch, B., The built environment and collective efficacy. Health \& Place, 14, pp. 198-208, 2008. 
[20] Forest Research. Benefits of green infrastructure. Report by Forest Research. Forest Research, Defra research contract number WC0807 Farnham, 2010.

[21] Lennon M., Douglas O. Scott M., Urban green space for health and well-being: developing an 'affordances' framework for planning and design. Journal of Urban Design, DOI: 10.1080/13574809.2017.1336058 Project: Eco-Health April 2017.

[22] Mekala, G.D., Jones, R.N., MacDonald, D.H., Valuing the benefits of creek rehabilitation: building a business case for public investments in urban green infrastructure. Springer Science Business Media New York. Environmental Management. DOI: 10.1007/ s00267-015-0471-7, 2015.

[23] Hartig, T., Mitchell, R., de Vries, S., Frumkin, H., Nature and health. Annual Review of Public Health, 35, 2014.

[24] Jennings, V., Larson, L., Yun, J., Advancing sustainability through urban green space: cultural ecosystem services, equity, and social determinants of health. International Journal of. Environmental Research Public Health, 13, p. 196, 2016.

[25] Kondo, M.C., South, E.C., Branas, C.C., Nature-based strategies for improving urban health and safety. Journal of. Urban Health, 2015.

[26] Ulrich, R.S., Simons, R.F., Losito, B.D., Fiorito, E., Miles, M.A., Zelson, M., Stress recovery during exposure to natural and urban environments. Journal of Environmental Psychology, 11, pp. 231-248, 1991.

[27] Tsai, W.-L., McHale, M., Jennings, V., Marquet, O., Hipp, J., Leung, Y.-F., Floyd, M., Relationships between characteristics of urban green land cover and mental health in U.S. metropolitan areas. International Journal of Environmental Research Public Health, 15, p. 340, 2018.

[28] Shanahan, D., Lin, B., Bush, R., Gaston, K., Dean, J., Barber, E., Fuller, R. Toward improved public health outcomes from urban nature. American Journal of Public Health, 105, pp. 470-477, 2015.

[29] Krekel, C., Kolbe, J., Wüstemann, H., The greener, the happier? The effects of urban green and abandoned areas on residential well-being. Ecological Economics 121, $117-$ $121,2016$.

[30] Valánszki, I., Fóris, D., Edina, Kovács F., Krisztina, Parallel development of green infrastructure and sustainable tourism - case studies from Hungary. Polish Journal of Natural Science, 33, pp. 625-647, 2018.

[31] Charles E. Little, Greenways for America, The Johns Hopkins University Press: Baltimore and London, 1990.

[32] M'Ikiugu, M., Qianna, W., \& Kinoshita, I., Green infrastructure gauge: a tool for evaluating green infrastructure inclusion in existing and future urban areas. Procedia Social and Behavioral Sciences, 68, pp. 815-825, DOI: 10.1016/j.sbspro.2012.12.269, 2012.

[33] NENW.The economic value of green infrastructure. NaturalEconomy Northwest(NENW). http://www.naturaleconomynorthwest.co.uk/resources+reports.php 2008.

[34] Greg Mcpherson, G., Simpson, J.R., Peper, P.J., Maco, S.E., and Xiao, Q., Municipal forest benefits and costs in five cities. Journal of Forestry, pp. 411-416, 2005.

[35] Krause B, Culmsee H, Wesche K, Bergmeler E, Leuschner C., Habitat loss of floodplain meadows in north Germany since the 1950s. Biodiversity and conservation, 20, pp. 2347-2364, 2011. 
[36] Dixon, K.K., and K.L., Wolf,. Benefits and risks of urban roadside landscape: finding a livable, balanced response. Proceedings of the 3rd Urban Street Symposium (June 2427, 2007; Seattle, WA). Washington, DC: Transportation Research Board of the National Academies of Science, 2007.

[37] Gill, S., Handley, J.F., Ennos, R., Pauleit, S., Adapting cities for climate change: the role of the green infrastructure. Built Environment, 33, pp. 115-133, DOI: 10.2148/ benv.33.1.115, 2007.

[38] Cotner, L., Minor, E., Zellner, M., Gonzalez-Meler, M., Jaffe, M., Belaire, A., Johnston, D., et al., The effectiveness of green infrastructure at improving water quality: a literature review, 2010.

[39] Cole,L., McPhearson, T., Herzog, C., Russ, A, Green infrastructure. Urban Environmental Education Review. Chapter: Educational Approaches. Cornell University, 2017.

[40] Berte E, Panagopoulos T., Enhancing city resilience to climate change by means of ecosystem services improvement: a SWOT analysis for the city of Faro, Portugal. International Journal of Urban Sustainable Development, 6, pp. 241-253, DOI: 10.1080/19463138.2014.953536, 2014.

[41] Russo A., Cirella, G.T., Edible green infrastructure for urban regeneration and food security: case studies from the Campania region. Agriculture, 10, p. 358, 2020. DOI: 10.3390/agriculture10080358, 2020.

[42] Carter, J., The potential of urban forestry in developing countries: a concept paper. FAO, Rome, 1995.

[43] Naderi, J., Kweon, B.-S., Maghelal, P., The street tree effect and driver safety. ITE Journal on the Web, 78, pp. 69-73, 2008.

[44] Singh, V.S., Pandey, D. N., Chaudhry, P., Urban forests and open green spaces: lessons for Jaipur, Rajasthan, and India. IN: RSPCB Occasional Paper No. 1. Rajasthan State Pollution Control Board 4-Jhalana Institutional Area, Jaipur 302017, Rajasthan, India, 2010.

[45] Dzhambov, A., Dimitrova, D. Green spaces and environmental noise perception. Urban Forestry \& Urban Greening, 14, pp. 1000-1008, 2015. DOI: 10.1016/j. ufug.2015.09.006.

[46] Litman, T.A.., Evaluating Accessibility for Transportation Planning. Victoria Transport Policy Institute ,1250 Rudiln Street,Victoria,BC,V8V 3R7,CANADA, 2008.

[47] Tom Godefrooij, Peter Snoeren and Roelof Wittink. Share the Road: Investment in Walking and Cycling Road Infrastructure UNEP, November 2010.

[48] C40 cities climate leader ship group. Benefits of Urban Climate Action. C40 Cities Technical Assistance Report, Addis Ababa 2020.

[49] Global Burden of Diseases. IHME data resource, 2016.

[50] Daniel Molla . Addis Ababa Road Safety strategy(2017-2030), Addis Ababa city administration and African transport policy programme, 2017.

[51] Tariku Ayana Abdi, Belay Hagos Hailu, Tamirie Andualem Adal, Pieter H.A.J.M. van Gelder, Marjan P., Road crashes in Addis Ababa, Ethiopia.emperical findings between the years 2010 and 2014. an international multidisciplinary journal, Ethiopia. AFRREV VOL.11(2) serial no.46:1-13, 2017.

[52] Jiregna Hirpaa, Solomon Zegeyeb, Martin Smallc , Tawia Addo-Ashongd .Preparation of a Road Safety Strategy for the City of Addis Ababa Addis Ababa Road Traffic 
Management Agency, Proceedings 2018 Australasian Road Safety Conference 3-5 October 2018, Sydney, Australia, 2018.

[53] Bekele, Teferi, ROAD TRAFFIC ACCIDENT CAUSE AND EFFECT ON SOCIO ECONOMY OF ADDIS ABABA CITY. Economics and Social Sciences Academic Journal Vol.1, No.4; 2019 ISSN (5282-0053); p - ISSN (4011-230X) , 2019.

[54] Michelle W.L. Fong., Technology leapfrogging for developing countries. Victoria University, Australia: Global Information Technology, 2009.

[55] Macmillandictionary. leapfrog definition https://www.macmillandictionary.com/ dictionary/british/leapfrog_1, 2020.

[56] Yetnayet Ayalnehe., Evaluating transport network structure case study in Addis Ababa Ethiopia. Enschede, the Netherlands, https://webapps.itc.utwente.nl > msc > gfm > bogale, February 2012.

[57] Todd A.Litman., Evaluating Accessibility for Transportation Planning. Measuring Ability To Reach Desired Goods and Activities. Victoria Transport Policy Institute, http://www.vtpi.org/access.pdf, 2012.

[58] Anca Alexe,. Curitiba, Brazil: the world's first sustainable city. UrbanizeHub, in Green Cities Projects \& Cities Urban policies \& Governance, February 5, 2017.

[59] Ali S., Sharifi, E. A case study of sustainable urban planning principles in Curitiba (Brazil) and their applicability in Shiraz (Iran). International Journal of Development and Sustainability, 1(2), pp. 120-134, 2012. https://isdsnet.com/ijds-v1n2.html. 